\title{
Analysis of naltrexone and its metabolite 6 - $\beta$-naltrexol in serum with high-performance liquid chromatography
}

Pekka Heinälä ${ }^{1,2}$, Tuuli Lahti ${ }^{1,3,5^{*}}$, David Sinclair ${ }^{1}$, Kari Ariniemi ${ }^{1}$, Pirjo Lillsunde ${ }^{1}$ and Hannu Alho ${ }^{1,4}$

\begin{abstract}
Background: Naltrexone has been proven to be an effective treatment option for the treatment of alcohol dependency. In this article we introduce a reliable and simple method developed for the simultaneous determination of naltrexone and 6- $\beta$-naltrexol in human serum by using high-performance liquid chromatography (HPLC).

Findings: Liquid-liquid extraction with butyl acetate from basic solutions $(\mathrm{pH}$ 9) was chosen for extraction with nalorphine as an internal standard (IS). Analytes were back-extracted from organic solvent into perchloric acid. The acid extract was chromatographed by HPLC with a reverse-phase ODS-column and electrochemical detector. The mobile phase was a $\mathrm{NaH}_{2} \mathrm{PO}_{4}$-solution with acetonitrile as an organic modifier and octanesulphonic acid and tetraethylammonium hydrogen sulphate as ion-pair reagents. The recovery of the extraction method was $48 \%$ for naltrexone and $75 \%$ for $6-\beta$-naltrexol. The limit of quantification was $5.0 \mathrm{ng} / \mathrm{ml}$ for naltrexone and $1.0 \mathrm{ng} / \mathrm{ml}$ for $6-\beta$-naltrexol. The analysed concentrations of naltrexone differed from the theoretic concentrations by 0.7 to $2.3 \%$ and those of $6-\beta$-naltrexol by $2.6 \%$. The relative standard deviation of within-day assay was from 0.9 to $5.7 \%$ for naltrexone and from 0.8 to $4.2 \%$ for $6-\beta$-naltrexol; for the between-day assay it was $5.7 \%$ and $4.2 \%$, respectively.
\end{abstract}

Conclusions: Our results indicate that the developed method is suitable for determination of naltrexone and 6- $\beta$-naltrexol in human serum.

Keywords: Naltrexone, 6- $\beta$-naltrexol, High-performance liquid chromatography, Alcoholism

\section{Findings}

Naltrexone is an opioid receptor antagonist, which has been used decades for the treatment of alcoholism [1-4] and opiate dependency [5-7]. Several well-controlled clinical trials have demonstrated that naltrexone is an efficacious adjunctive medication in the treatment of alcoholism [2,8,9]. Naltrexone has shown to reduce relapse rates and alcohol craving among alcoholics as compared to placebo-treated individuals [2]. Once administered, naltrexone is known to undergo a rapid and extensive hepatic metabolism by enzymatic reduction from ketone to a major metabolite 6- $\beta$-naltrexol (Figure 1) and to other minor metabolites. 6 - $\beta$-naltrexol is weaker

\footnotetext{
* Correspondence: tuuli.lahti@thl.fi

${ }^{1}$ National Public Health Institute, Helsinki, Finland

${ }^{3}$ Department of Behavioural Sciences and Philosophy, University of Turku, Turku, Finland

Full list of author information is available at the end of the article
}

opioid receptor antagonist than naltrexone, but it may contribute to the clinical effects of the drug as it persists in biological fluids in higher amounts than naltrexone [10]. Naltrexone and its metabolites are mostly present in conjugated forms [11-13]. Less reduction of naltrexone to 6- $\beta$-naltrexol seems to occur in liver cirrhosis, and such alterations appear to be related to the severity of liver disease $[14,15]$.

Several methods for therapeutic drug monitoring of naltrexone and 6- $\beta$-naltrexol have been developed over the years. These include gas chromatography with electron capture detection (GC-ECD) $[13,16]$, high-performance liquid chromatography with electrochemical detection (HPLC-EC) [17,18], gas chromatography-mass spectrometry (GC-MS) [19,20], and gas chromatography-tandem mass spectrometry (GC-MS-MS) [21]. Recently Brünen et al. [22] introduced two novel methods, HPLC/UV (high-performance liquid chromatography and UV

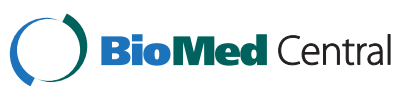




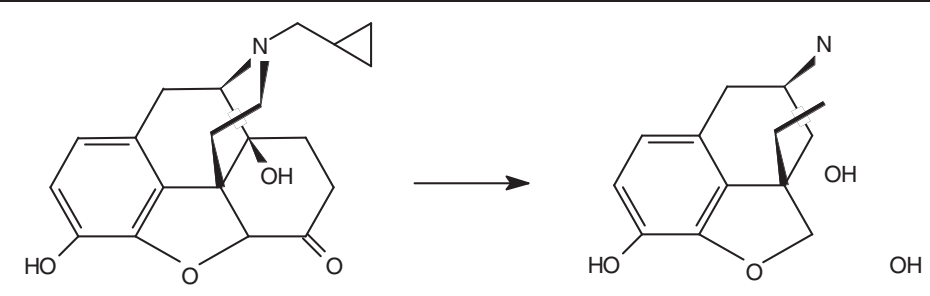

Naltrexone

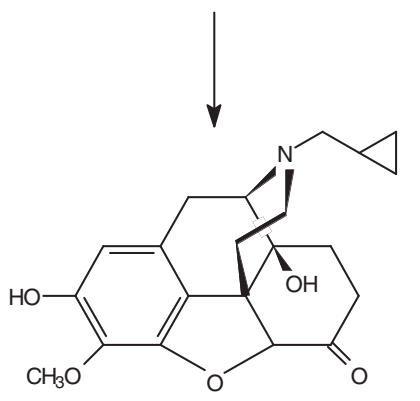

2-hydroxy-3-methoxy-naltrexone
6 - $\beta$-naltrexol

$\mathrm{OH}$

2-hydroxy-3-methoxy-6- $\beta$-naltrexol<smiles>CCC1(O)COc2c(OC)c(O)cc3c2C1(CC)CC(N)C3</smiles>

Figure 1 Metabolism of Naltrexone.

spectrophotometric detection) and LC-MS/MS (liquidchromatographic method coupled with tandem mass spectrometry), for the determination of naltrexone and 6- $\beta$-naltrexol. The methods developed by Brünen et al. [22] have several benefits, such as better automatization and higher sensitivity, as compared to other methods developed for the simultaneous quantitative determination of naltrexone and 6- $\beta$-naltrexol in biological fluids.

With therapeutic drug monitoring the treatment outcomes of drugs can be significantly improved. It has been suggested that therapeutic drug monitoring should be a standard protocol while using naltrexone for the treatment of substance abuse [23]. Thus we aimed to develop even more efficient analysis method for determi-nation of naltrexone and $6-\beta$-naltrexol in human serum than has been earlier developed. To achieve this goal we used liquid-liquid extraction and subsequent analysis by HPLC with electrochemical detection for determination of naltrexone and 6 - $\beta$-naltrexol in human serum.

\section{Materials and methods}

The naltrexone (Dupont Merck) and 6- $\beta$-naltrexol (NIDA) stock solutions were prepared in methanol to give concentrations of $1 \mathrm{mg} / \mathrm{ml}$ of free base. These solutions were used to prepare calibration curves covering

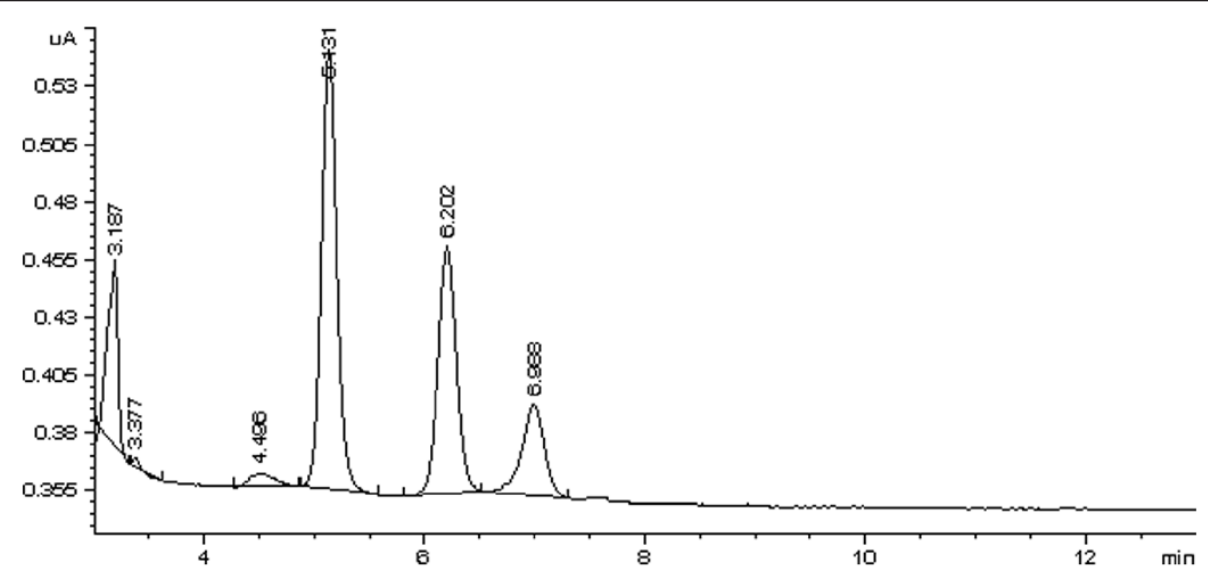

Figure 2 A chromatogram of a serum standard containing $50 \mathrm{ng} / \mathrm{ml}$ naltrexone $(\mathrm{RT}=6.99)$ and $6-\beta$ - naltrexol $(\mathrm{RT}=6.20)$, nalorphine $(R T=5.13)$ as internal standard. 


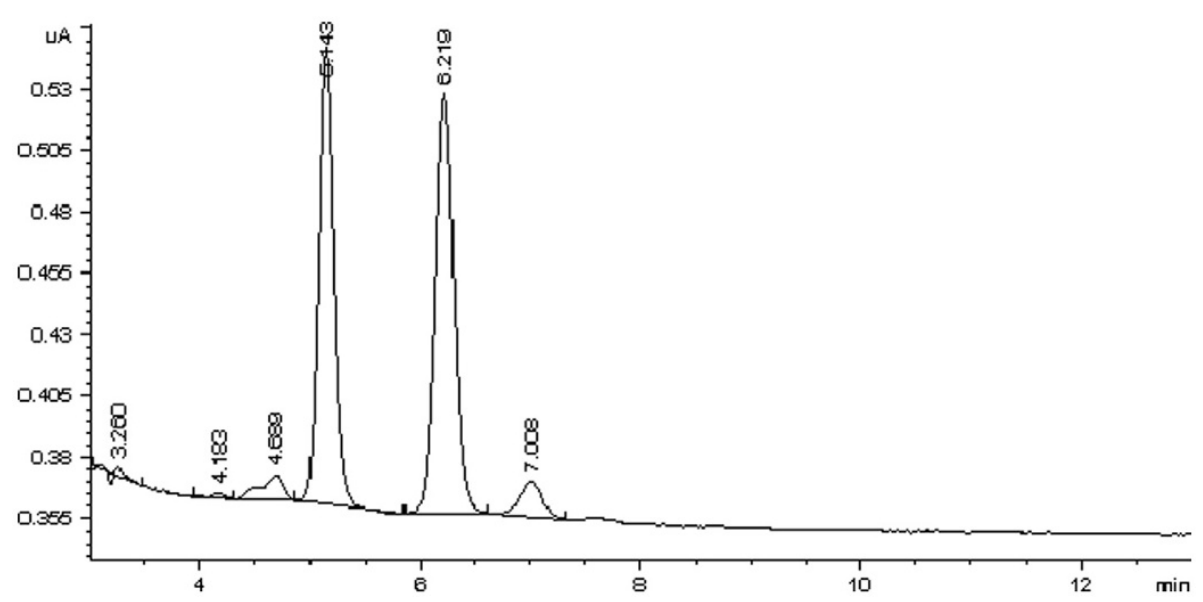

Figure 3 A chromatogram of a patient sample containing naltrexone $(\mathrm{RT}=7.00)$ and 6- $\beta$-naltrexol $(6.22)$, nalorphine as internal standard $(\mathrm{RT}=5.14)$.

the range from 0 to $1000 \mathrm{ng} / \mathrm{ml}$. All calibration standards, blanks and quality control samples, were prepared in drug-free cattle serum. All buffers were prepared with deionized water.

\section{Clinical sampling}

Samples from 87 (23 women and 64 men) alcoholics (DSM-IV) were taken. The alcoholics were participating in a double blind, placebo-controlled, prospective clinical trial evaluating naltrexone in the treatment of alcohol dependence. The main inclusion criteria were: age between 18-65, alcohol dependency (DSM-IV and ICD-10). Naltrexone (naltrexone $\mathrm{HCl}, \mathrm{ReVia}^{\circledR}$ ) was taken daily $50 \mathrm{mg}$ orally every morning for a threemonth period. The blood sample was collected approximately $2-4 \mathrm{~h}$ after the medication consumption. Fasting serum samples were collected by vein puncture at weeks 0,2 , and 8 , and allowed to clot, and centrifuged (1000 g, $10 \mathrm{~min}$, at room temperature). All samples were stored at $-70^{\circ} \mathrm{C}$ until analysis.

\section{Extraction}

$1 \mathrm{ml}$ of serum was extracted for all standard, quality control, and unknown clinical samples. The $\mathrm{pH}$ of the sample was adjusted to $\mathrm{pH} 9$ by $0.5 \mathrm{M} \mathrm{Na}_{2} \mathrm{HPO}_{4} \cdot 2 \mathrm{H}_{2} \mathrm{O}$. The sample was extracted with $5 \mathrm{ml}$ of butyl acetate with nalorphine $(1 \mu \mathrm{g} / 100 \mathrm{ml})$ as the internal standard. After

Table 1 The linearity range, mean correlation coefficient $\left(r^{2}\right)$, and limit of quantification(LQ) with RSD-value for naltrexone and 6- $\beta$-naltrexol

\begin{tabular}{|c|c|c|c|c|}
\hline Compound & Linearity range (ng/ml) & $r^{2}$ & LQ (ng/ml) & RSD (\%) \\
\hline Naltrexone & $5-1000$ & 0.9987 & 5 & 5.7 \\
\hline 6- $\beta$-naltrexol & $1-1000$ & 0.992 & 1 & 15.4 \\
\hline
\end{tabular}

vortex-mixing (30 s), the sample was centrifuged, and the upper butyl acetate layer was transferred to a clean test tube and back-extracted into $150 \mu \mathrm{l}$ of $0.1 \mathrm{M} \mathrm{HClO}_{4}$. After vortex-mixing (30 s) and centrifugation, the upper butyl acetate phase was thrown out. The acid phase was transferred to the autosampler vial, and $25 \mu \mathrm{l}$ of the acid phase was injected into the HPLC.

\section{Chromatographic conditions}

A Hewlett-Packard 1090 Series II high-performance liquid chromatography with an Esa Coulochem 5100A electrochemical coulometric detector (potentials: Detector $1+0.2 \mathrm{~V}$, Detector $2+0.5 \mathrm{~V}$ ) was used. The mobile phase was acetonitrile-potassium dihydrogen phosphate $(19 \mathrm{mM}) \quad(10: 45, \mathrm{v} / \mathrm{v})$ with 1-octanesulphonic acid (5 $\mathrm{mM})$ and tetraethylammonium hydrogen sulphate (5 $\mathrm{mM})$ as ion-pair reagents. Chromatographic separation was achieved using an ODS Hypersil reversephase column (Hewlett Packard) with a length of $125 \mathrm{~mm}$, an i.d. of $4 \mathrm{~mm}$, and a particle size of $5 \mu \mathrm{m}$. The mobile phase was pumped at a flow-rate of $1.2 \mathrm{ml} / \mathrm{min}$.

The identification of drugs was based on retention times, which were checked with calibration standards before each run. An internal standard method with linear one-point calibration based on peak heights was used for quantification. Reliability of the method was tested for linearity, accuracy, and within-day and between-day assay precision. The suitability for determination of naltrexone and its major metabolite was tested by analysing serum samples from patients participated in alcoholism treatment with naltrexone.

\section{Results and discussion}

Chromatograms of the control samples spiked with naltrexone and 6- $\beta$-naltrexol and an unknown clinical 
Table 2 Average concentrations found, accuracy and within-day assay precision for naltrexone and 6- $\beta$-naltrexol

\begin{tabular}{lcccc}
\hline Compound & Concentration added $\mathbf{n g} / \mathbf{m l})$ & Concentration found $\mathbf{( n g} / \mathbf{m l})$ & Accuracy $(\%)$ & Precision $(\%)$ \\
\hline Naltrexone & 5 & 4.97 & 0.7 & 5.7 \\
& 150 & 146.6 & 2.3 & 0.9 \\
6- $\beta$-naltrexol & 5 & 4.87 & 2.6 & 4.2 \\
& 150 & 146.1 & 2.6 & 0.8 \\
\hline
\end{tabular}

serum sample are all shown in Figures 2 and 3. The retention times (min) of nalorphine (IS), 6- $\beta$-naltrexol, and naltrexone were 5.1, 6.1, and 6.9, respectively. The extraction recoveries at three concentration levels $(100$, 250 , and $500 \mathrm{ng} / \mathrm{ml}$ ) varied from 46.5 to $50.7 \%$ for naltrexone and from 71.6 to $77.4 \%$ for 6 - $\beta$-naltrexol. Two sets of standard samples were prepared at a concentration range from 0 to $1000 \mathrm{ng} / \mathrm{ml}$ to determine the linearity. The linearity ranges and the mean correlation coefficients $\left(\mathrm{r}^{2}\right)$ for naltrexone and 6- $\beta$-naltrexol are shown in Table 1 . The method was linear wide over the concentration range of naltrexone and $6-\beta$-naltrexol in clinical samples.

The limit of quantification was determined by analysing sets of six samples at low concentration levels. Relative standard deviations (RSD) of these samples were calculated. Signal-to-noise ratio of at least three and RSD-values below $20 \%$ were used as criteria for the limit of quantification. The limits of quantification with RSDvalues for both compounds are shown in Table 1. The accuracy and within-day precision of the assay was tested at two concentration levels and with six samples. The average of concentrations found, the accuracy, and the within-day assay precision for naltrexone and 6 - $\beta$-naltrexol are shown in Table 2.

Between-day precision of the assay was determined by analysing the same serum standard 15 times in 30 days. A serum standard, spiked with $100 \mathrm{ng} / \mathrm{ml}$ of naltrexone and $6-\beta$-naltrexol, was stored at $-20^{\circ} \mathrm{C}$. The average concentrations found were 98.8 and $98.9 \mathrm{ng} / \mathrm{ml}$, and between-day assay precision was $5.7 \%$ and $4.2 \%$ for naltrexone and 6 - $\beta$-naltrexol, respectively. Small changes in laboratory conditions (room temperature, atmospheric moisture) had no effect on the results. Retention times seemed to increase slightly because of contamination within the chromatographic system. This had, however, no effect on results because the retention times were checked with calibration standards before each determination. Although the extraction recovery was relatively low, the accuracy and the precision were good. The specific stability validation was not performed, but the between-day precision showed that the serum standard samples were stable for 30 days at $-20^{\circ} \mathrm{C}$. The clinical serum samples were stored at $-70^{\circ} \mathrm{C}$.
On the basis of validation results, the developed method was found suitable for determination of naltrexone and 6- $\beta$-naltrexol in human serum. The within-day and between-day assay precision was acceptable for all tested concentration levels. The developed method was used for determination of naltrexone and $6-\beta$-naltrexol in serum samples from patients participating in naltrexone treatment of alcoholism. Analysed serum samples were collected after two and eight weeks of continuous naltrexone treatment. Concentrations of naltrexone and its major metabolite in serum samples varied greatly between patients. Naltrexone concentrations in serum were $0-70 \mathrm{ng} / \mathrm{ml}$ after two weeks and $0-19 \mathrm{ng} / \mathrm{ml}$ after eight weeks of continuous naltrexone treatment. $6-\beta$-naltrexol concentrations were $15-136 \mathrm{ng} / \mathrm{ml}$ and $3-163 \mathrm{ng} / \mathrm{ml}$ after two and eight weeks, respectively. 6 - $\beta$-naltrexol seemed to be the more reliable compound to monitor because some unidentified compound was found to interfere with the quantification of naltrexone. The laboratory verification demonstrated the tests were accurate in showing the levels of naltrexone and naltrexol in serum samples, but high variability was seen in the results from patients reporting that they were taking naltrexone. The reasons for the variability in practice remain to be determined but could have an influence on the efficacy of the treatment.

\section{Abbreviations \\ HPLC: High-performance liquid chromatography; IS: Internal standard; GC-ECD: Gas chromatography with electron capture detection; HPLC-EC: High-performance liquid chromatography with electrochemical detection; GC-MS: Gas chromatography-mass spectrometry; GC-MS-MS: Gas chromatography-tandem mass spectrometry; RSD: Relative standard deviations.}

\section{Competing interests}

The authors declare that they have no competing interests.

\section{Authors' contributions}

$\mathrm{PH}$ participated in the design of the study, made substantial contributions to the analysis of the data and drafted the manuscript. TL and DS were involved in drafting and revising the manuscript and in the interpretation of the data. KA and PL conceived of the study, and participated in its design and coordination. HA participated to the design and acquisition of the data as well as to the interpretation of the data. All authors read and approved the final manuscript.

\section{Author details}

${ }^{1}$ National Public Health Institute, Helsinki, Finland. ${ }^{2}$ Finnish Foundation for Alcohol Studies, Helsinki, Finland. ${ }^{3}$ Department of Behavioural Sciences and Philosophy, University of Turku, Turku, Finland. ${ }^{4}$ Research Unit of Substance 
Abuse Medicine, University of Helsinki, Helsinki, Finland. ${ }^{5} \mathrm{THL}, \mathrm{PL}$ 30, 00271 Helsinki, Finland.

Received: 3 January 2012 Accepted: 2 August 2012

Published: 15 August 2012

\section{References}

1. Litten RZ, Allen JP: Advances in development of medications for alcoholism treatment. Psychopharmacology 1998, 139:20-33.

2. Volpicelli JR, Alterman Al, Hayashida M, O'Brien CP: Naltrexone in the treatment of alcohol dependence. Arch Gen Psychiatry 1992, 49:876-879.

3. O'Malley SS: Opioid antagonists in the treatment of alcohol dependence: Clinical efficacy and presentation of relapse. Alcohol Alcohol 1996, 1:77-81.

4. Anton RF, O'Malley SS, Ciraulo DC, Cisler RA, Couper D, Donovan DM, Gastfriend DR, Hosking JD, Johnson BA, LoCastro JS, Longabaugh R, Mason BJ, Mattson ME, Miller WR, Pettinati HM, Randall CL, Swift R, Weiss RD, Williams LD, Zweben AZ, for the COMBINE Study Research Group: Combined pharmacotherapies and behavioral interventions for alcohol dependence: The COMBINE Study: A Randomized Controlled Trial. JAMA 2006, 295:2003-2017.

5. Renault PF: Treatment of heroin-dependent persons with antagonists: Current status. Bull Narc 1978, 30:21-29.

6. Krupitsky E, Zvartau E, Masalov D, Tsoy M, Burakov A, Egorova V, Didenko T, Romanova T, Ivanova E, Bespalov A, Verbitskaya EV, Neznanov NG, Grinenko AY, O'Brien CP, Woody GE: Naltrexone with or without fluoxetine for preventing relapse to heroin addiction in St. Petersburg, Russia. J Subst Abuse Treat 2006, 31:319-328.

7. Crabtree BL: Review of naltrexone, a long-acting opiate antagonist. Clinical Pharmacology 1984, 3:273-280.

8. O'Malley S, Jaffe AJ, Chang G, Schottenfeld RS, Meyer RE, Rounsaville B: Naltrexone and coping skills therapy for alcohol dependence. Arch Gen Psychiatry 1992, 49:881-887.

9. Volpicelli JR, Rhines KC, Rhines JS, Volpicelli LA, Alterman Al, O'Brien CP: Naltrexone and alcohol dependence: role of subject compliance. Arch Gen Psychiatry 1997, 54:737-742.

10. Therapeutic Drugs 2: Therapeutic Drugs 2. London: Churchill Livingstone; 1993.

11. Wall ME, Brine DR, Perez-Reyes M: The metabolism of naltrexone in man. Naltrexone Research Monograph 1980, 28:105-131.

12. Wall ME, Brine DR, Perez-Reyes M: Metabolism and disposition of naltrexone in man after oral and intravenous administration. Drug Metab Dispos 1981, 9:369-375.

13. Verebey K, De Pace A, Jukofsky D, Volavka JV, Mule SJ: Quantitative determination of 2-hydroxy-3-methoxy-6-beta-naltrexol (HMN), naltrexone, and 6-beta-naltrexol in human plasma, red blood cells, saliva and urine by gas liquid chromatography. J Anal Toxicol 1980, 4:33-37.

14. McCaul ME, Wand GS, Sullivan J, Mummford G, Quigley J: Beta-naltrexol level predicts alcohol relapse. Alcohol Clin Exp Res 1997, 21:32A.

15. Bertolotti M, Ferrari A, Vitale G, Stefani M, Trenti T, Loria P, et al: Effect of liver cirrhosis on the systemic availability of naltrexone in humans. J Hepatol 1997, 27:505-511.

16. Reuning RH, Ashcraft SB, Morrison BE: An electron-capture gas chromatographic assay for naltrexone in biological fluids. Naltrexone Research Monograph 1980, 28:25-35.

17. Davidson AF, Emm TA, Pieniaszek HJ: Determination of naltrexone and its major metabolite, 6- $\beta$-naltrexol, in human plasma using liquid chromatography with electrochemical detection. J Pharm Biomed Anal 1996, 14:1717-1725

18. Zuccaro P, Altieri I, Betto P, Pacifici R, Ricciarello G: Determination of naltrexone and $6-\beta$-naltrexol in plasma by high-performance liquid chromatography with coulometric detection. J Chromatogr 1991, 567:485-490.

19. Monti KM, Foltz RL, Chinn DM: Analysis of naltrexone and 6- $\beta$-naltrexol in plasma and urine by gas chromatography/negative ion chemical ionization mass spectrometry. J Anal Toxicol 1991, 15:136-140.

20. Huang W, Moody DE, Foltz RL: Determination of naltrexone and 6- $\beta$-naltrexol in human plasma by solid-phase extraction and gas chromatography- negative ion chemical ionization-mass spectrometry. J Anal Toxicol 1997, 21:252-257.
21. Nelson CC, Fraser MD, Wilfahrt JK, Foltz RL: Gas chromatography/ tandem mass spectrometry measurement of $\Delta^{9}$-tetrahydrocannabinol, naltrexone and their active metabolites in plasma. Ther Drug Monit 1993 15:557-562.

22. Brünen $S$, Krüger R, Finger $S$, Korf F, Kiefer F, Wiedemann K, Lackner KJ, Hiemke C: Determination of naltrexone and 6beta-naltrexol in human blood: comparison of high-performance liquid chromatography with spectrophotometric and tandem-mass-spectrometric detection. Anal Bioanal Chem 2010, 396(3):1249-1257.

23. Brünen S, Vincent PD, Baumann P, Hiemke C, Havemann-Reinecke U: Therapeutic drug monitoring for drugs used in the treatment of substance-related disorders: literature review using a therapeutic drug monitoring appropriateness rating scale. Ther Drug Monit 2011, 33(5):561-572

\section{doi:10.1186/1756-0500-5-439}

Cite this article as: Heinälä et al:: Analysis of naltrexone and its metabolite

6- $\beta$-naltrexol in serum with high-performance liquid chromatography.

BMC Research Notes 2012 5:439.

\section{Submit your next manuscript to BioMed Central and take full advantage of:}

- Convenient online submission

- Thorough peer review

- No space constraints or color figure charges

- Immediate publication on acceptance

- Inclusion in PubMed, CAS, Scopus and Google Scholar

- Research which is freely available for redistribution 